\title{
The effects of taxpayer knowledge and taxation socialization on taxpayer compliance: The role of taxpayer awareness in developing Indonesian economy
}

\author{
Rachmawati Meita Oktaviani ${ }^{a^{*}}$, Hanif Kurnia ${ }^{a}$, Sunarto ${ }^{a}$ and Udin ${ }^{b}$
}

\author{
${ }^{a}$ Universitas Stikubank, Indonesia

\begin{tabular}{l}
\hline C H R O N I C L E \\
\hline Article history: \\
Received October 302019 \\
Received in revised format \\
November 252019 \\
Accepted November 302019 \\
Available online \\
December 112019 \\
\hline Keywords: \\
Taxpayer knowledge \\
Taxation socialization \\
Taxpayer awareness \\
Taxpayer compliance \\
\hline
\end{tabular}

${ }^{b}$ Universitas Muhammadiyah Yogyakarta, Indonesia

\section{A B S T R A C T}

\begin{abstract}
The purpose of this study is to analyze the effects of taxpayer knowledge and taxation socialization on taxpayer compliance mediated by taxpayer awareness. This study uses purposive sampling for determining respondents from taxpayers of free workers registered in the west Semarang, Indonesia. Data is analyzed using regression and path analysis. The results of the study reveal that taxpayer knowledge and taxation socialization had a significant effect on taxpayer compliance and awareness. Taxpayer awareness further partially mediates the relationships between taxpayer knowledge and taxation socialization on taxpayer compliance. Therefore, for developing Indonesian economy, the government should provide an understanding that people are required to pay taxes voluntarily and with full awareness as good citizens.
\end{abstract}

(C) 2020 by the authors; licensee Growing Science, Canada

\section{Introduction}

Tax is a mandatory contribution to the state-owned by individuals or legal entities that are forced based on the act, with no direct compensation, and it is used for the country's needs for the amount of prosperity of the people (UU No. 6 1983). Compliance with taxpayers is defined as the behavior of a taxpayer in carrying out all tax obligations and using his taxation rights while adhering to the laws and regulations (Marjan, 2014). The low level of tax compliance is the center of government attention because non-compliance of taxpayers can lead to the intention of tax avoidance or deliberately unwilling to pay tax obligations. This behavior indirectly causes a decrease in tax revenue received by the state. Taxpayers should own knowledge of tax. According to Utami et al. (2012), knowledge is the information that is known or realized by someone. Knowledge of taxation is the most essential thing that should be possessed by taxpayers because without knowledge of taxation, it is difficult for taxpayers to carry out their tax obligations, such as paying taxes and reporting taxes (Melando \& Waluyo, 2013). According to Indrawan (2014), in addition to the perception of the effectiveness of the taxation system that can affect taxpayer awareness in paying taxes, knowledge of tax regulations can affect taxpayer awareness in paying taxes. Tax socialization is an effort made by the Directorate General of Taxes to provide knowledge to the public and especially taxpayers to know everything about taxation, both regulations and taxation procedures, through appropriate methods (Saragih, 2013). Taxation socialization from counseling and advertising includes the dissemination of information about the rights and obligations of a taxpayer. Efforts to increase awareness and compliance of taxpayers are carried out by promoting taxation in various forms (Sugeng, 2012). However, socialization activities must be carried out effectively and carried out through media that is more readily accepted by the community (Herryanto, 2013).

* Corresponding author.

E-mail address: meitarachma@edu.unisbank.ac.id (R. M. Oktaviani) 
According to the head of the counseling, service, and public relations department of the Regional Office, Rasjid, in his research (Lianty et al., 2017), understanding and awareness of the Indonesian people to obey paying taxes is still minimal. It is because of the knowledge about taxes obtained by the public is not optimal. The level of tax ratio, which is still low, indicates the lack of public awareness in paying taxes (Sucipto, 2016). The concern in paying taxes will be difficult to realize if, in the sense of tax, there are no elements that can be forced. This element provides an understanding that people are required to pay taxes voluntarily and with full awareness as good citizens. Compliance of taxpayers is the fulfillment of tax obligations performed by taxpayers to contribute to the expected development of the country, which is done voluntarily (Tiraada, 2013). According to Nurmantu (2005), taxpayers are said to be compliant when they have fulfilled all their tax obligations. The factor influencing a country's tax revenue is the level of tax compliance in the community (Chau, 2009). Compliance with taxpayers in fulfilling their tax obligations can increase state cash receipts and increase tax ratios (Nurmantu, 2007 in Harinurdin, 2009).

Awareness of taxpayers is needed because taxes function as state funding so that taxpayer compliance can be improved (Jatmiko, 2006). The study of Jatmiko (2006) shows that taxpayer awareness has a positive effect on taxpayer compliance. Similar results were also stated by Muliari and Setiawan (2011) that there is a positive relationship between taxpayer awareness and compliance with personal taxpayer reporting. But the research of Zahra (2017) shows different results, that taxpayer awareness does not affect taxpayer compliance. It is also supported by Lestari (2018), which concluded that taxpayer awareness does not affect taxpayer compliance. Various studies examine the factors that influence taxpayer awareness. The influence of knowledge, quality, socialization, and tax sanctions on the behavior of taxpayers has done a lot with different results. Some research states that taxpayer knowledge has a positive effect on taxpayer compliance (Manuputty \& Sirait, 2016 Widawati, 2017; Suryani et al., 2018). However, different research results are shown by Zahra (2017) that knowledge does not affect taxpayer compliance. The quality of service, according to Syarifudin (2016), Astuti (2017) and Susmita and Supadmi (2016), affects the compliance of taxpayers. However, the results of research conducted by Lestari (2018) and Endaryanti (2017) state that service quality does not affect tax compliance. Research conducted by Widawati (2017) and Boediono et al. (2018) state that tax socialization has a positive effect on taxpayer compliance. But the study conducted by Setyaningrum (2017) found that tax socialization does not affect taxpayer compliance. Therefore, further research is still needed to confirm the relationship between some of these variables. This study developed a research model by adding taxpayer awareness as a mediating variable. Knowledge about reasonable taxation and the socialization that is often carried out by the tax authorities does not necessarily have an impact on taxpayer compliance. It is reinforced by the level of tax ratios that are still low, which shows the lack of public awareness in paying taxes (Sucipto, 2016).

\section{Literature Review and Hypotheses Development}

\subsection{Taxpayer Knowledge and Awareness}

The higher the taxpayer's knowledge, the better the taxpayer can determine their behavior well and following tax regulations. If the taxpayer does not know tax regulations and processes, the taxpayer cannot resolve his/her response correctly. Based on the theory of specific attribution, knowledge of taxation is used to determine the behavior of taxpayers towards the awareness of taxpayers in paying their tax obligations. The result of Satiti (2016) states that tax knowledge has a significant effect on taxpayer awareness. It is consistent with research conducted by Syahputri et al., (2014) and Manuputty and Sirait (2016) that tax knowledge has a significant effect on taxpayer awareness. Thus,

$\mathrm{H}_{1}$ : Taxpayer knowledge has a positive effect on taxpayer awareness.

\subsection{Tax Socialization and Taxpayer Awareness}

Intensive tax socialization can increase the understanding of taxpayers about the obligation to pay taxes as a form of national cooperation in collecting funds for the benefit of government financing and national development (Kurniawan et al., 2014). Based on the theory of consistency attribution, if the taxation socialization given by the Director-General of Taxes were previously considered less effective by the taxpayer, this could make taxpayers less aware of paying taxes. Boediono et al. (2018) and Syahputri et al. (2014) support the statement that tax socialization affects taxpayer awareness. The results of this study are supported by Yuwono (2015) that tax socialization has a positive effect on taxpayer awareness. Therefore,

$\mathrm{H}_{2}$ : Tax socialization has a positive effect on taxpayer awareness.

\subsection{Taxpayer Awareness and Taxpayer Compliance}

Awareness that tax is a form of participation in supporting the country's development. Taxpayers who are aware of willing to pay taxes feel they are not disadvantaged from tax collection carried out, resulting in increased taxpayer compliance ( Hardiningsih \& Yulianawati, 2011). The study of Hartana and Merkusiwati (2018) found a positive relationship between taxpayer awareness of taxpayer compliance. Ibtida (2010) also found a significant influence of the awareness of taxpayers on 
taxpayer compliance. Astuti (2017) found that there is a positive correlation between taxpayer awareness and taxpayer compliance. It means that the higher the awareness of taxpayers to pay their tax obligations, the compliance of taxpayers in paying taxes will increase. Thus,

$\mathrm{H}_{3}$ : Taxpayer awareness has a positive effect on taxpayer compliance.

\subsection{Taxpayer Knowledge and Taxpayer Compliance}

According to Budhiartama (2016), someone who has education about tax will know about taxation that will be useful for their lives. Knowledge of taxation will help taxpayers to pay taxes so that the level of compliance will increase. Attribution theory states that taxpayer knowledge of tax regulations is an internal cause that can affect taxpayers in paying taxes. It is supported by Manuputty and Sirait (2016) that tax knowledge has a positive effect on taxpayer compliance. Astuti (2017) supports previous research that there is a positive influence between tax knowledge on tax compliance. It means that the better the taxation knowledge possessed by the taxpayer, the better the compliance of the taxpayer. Thus,

$\mathrm{H}_{4}$ : Taxpayer knowledge has a positive effect on taxpayer compliance.

\subsection{Tax Socialization and Taxpayer Compliance}

Socialization can increase knowledge about tax, which will later have an impact on the rising compliance of taxpayers themselves in carrying out their tax obligations. Tax information dissemination will provide an understanding for taxpayers regarding tax procedures, regulations, and sanctions if they do not comply (Widawati, 2017). According to attribution theory, a person's behavior is influenced by internal or external factors. Both factors are expected to motivate taxpayers to be obedient in paying taxes so that tax socialization can improve taxpayer compliance in paying taxes. This is supported by the research conducted by Yuwono (2015) and Boediono et al. (2018) that tax socialization affects taxpayer compliance. By increasing tax socialization to the public, this can increase taxpayer compliance in paying taxes. Thus,

$\mathrm{H}_{5}$ : Tax socialization has a positive effect on taxpayer compliance.

\section{Research Methods}

\subsection{Respondents}

The population in this study is free labor taxpayers registered at the West Semarang - Indonesia Tax Office (KPP). This study uses purposive sampling so that the number of samples used is 95 respondents.

\subsection{Measurements}

Knowledge of taxpayers is measured using 6 question indicators. The measurement scale used is a 5-point Likert scale. Tax socialization is also measured using 6 question indicators (Sugeng, 2012). Tax awareness is measured using 5 question indicators (Budhiartama \& Jati, 2016). Tax compliance is measured using 6 question indicators (Andiko et al., 2018).

Table 1

Descriptive Statistics

\begin{tabular}{llcccc}
\hline \multicolumn{1}{c}{ Variable } & N & Minimum & Maximum & Mean & Std. Deviation \\
\hline Knowledge & 95 & 3.00 & 5.00 & 4.00 & 0.427 \\
Socialization & 95 & 3.00 & 5.00 & 4.04 & 0.482 \\
Awareness & 95 & 3.00 & 5.00 & 4.10 & 0.484 \\
Compliance & 95 & 3.00 & 5.00 & 4.08 & 0.375 \\
Valid N (Listwise) & 95 & & & & \\
\hline
\end{tabular}

Table 2

Results of Regression and Hypothesis Testing (1)

\begin{tabular}{lccccc}
\hline & Variable & Sig.F & Adjusted R2 & Sig. & Beta \\
\hline Regression & 0.000 & 0.480 & & & \\
Knowledge & & & 0.000 & 0.380 & Accepted \\
Socialization & & & 0.000 & 0.508 & Accepted \\
\hline
\end{tabular}

Table 3

Results of Regression and Hypothesis Testing (2)

\begin{tabular}{lccccc}
\hline & Variable & Sig.F & Adjusted R2 & Sig. & Beta \\
\hline Regression & 0.000 & 0.706 & & & \\
Knowledge & & & 0.033 & 0.140 & Accepted \\
Socialization & & & 0.126 & 0.108 & Rejected \\
Awareness & & 0.000 & 0.700 & Accepted \\
\hline
\end{tabular}


The technique of data analysis in this study applied was path analysis. The path analysis was chosen since the study involved awareness as a mediating variable. The analysis technique was carried out as revealed by Sandjojo (2011) that path analysis was a research method primarily used to test the strength of direct and indirect relationships between various variables.

\section{Results}

The results of this study indicate that based on gender, out of 95 respondents, $60 \%$ are female, and $40 \%$ are male. It shows that females dominate the majority of respondents who are free worker taxpayers who are registered with the West Semarang KPP.

The age characteristics of the respondents from the survey results show that the most age group is in the 30-39 years age group, which is $49.5 \%$. This indication shows that the respondent is in an age that is mature enough to be able to give a better response.

\subsection{Validity and Reliability Testing}

The validity test in this study is known that the determinant of tax compliance with awareness as a mediating variable has a $\mathrm{KMO}$ level above 0.5 . The loading factor for the indicator of the question raised represents a variable greater than 0.4 . It shows that all instruments used in this study are valid. While the reliability test results for all variables are more than 0.7 so that this research variable can be said to be reliable.

\subsection{Results of Path Analysis}

In Table 3, it is known that awareness and knowledge are proven to influence compliance. It is evidenced through the fit model with a significance level of 0.000 , while socialization does not affect compliance, with the fit model at a significance level of 0.126 . Adjusted $\mathrm{R}^{2}$ value shows that the coefficient of determination of the results of this study is $70.6 \%$, namely compliance is influenced by knowledge and awareness, while other variables outside the model influenced $29.4 \%$ of the study.

\subsection{Hypothesis Testing}

Table 2 shows that the significance value at $\mathrm{H} 1$ is 0.000 , with a beta value of 0.380 . These results indicate a significance value of less than $5 \%$, so $\mathrm{H} 1$ is accepted. The significance value at $\mathrm{H} 2$ is 0.000 , with a beta value of 0.508 . These results indicate a significance value of less than $5 \%$, so $\mathrm{H} 2$ is accepted. The significance value at $\mathrm{H} 3$ is 0.000 , with a beta value of 0.700 . These results indicate a significance value of less than 5\%, so $\mathrm{H} 3$ is accepted. Table 3 also shows that the significance value at $\mathrm{H} 4$ is 0.033 , with a beta value of 0.140 . These results indicate a significance value of less than $5 \%$, so $\mathrm{H} 4$ is accepted. The significance value at $\mathrm{H} 5$ is 0.126 , with a beta value of 0.108 . These results indicate a significance value of more than $5 \%$, so $\mathrm{H} 5$ is rejected. The results of the first model path test, namely, the analysis of the effect of X1 through Y1 on Y2, it is known that the direct effect given X1 to Y2 is 0.140 . While the indirect effect of X2 through Y1 on Y2 is $(0.380 \times 0.700=0.266)$. Based on the results of this calculation, it is known that the value of the direct effect is 0.140 and indirect effect is 0.266 , which means that the value of the indirect effect is greater than the value of the direct effect. These results indicate that taxpayer awareness can mediate a partial relationship between taxpayer knowledge and compliance. Path analysis in the second model, namely, the analysis of the influence of $\mathrm{X} 2$ through $\mathrm{Y} 1$ to $\mathrm{Y} 2$, has shown that the direct effect given by $\mathrm{X} 2$ to $\mathrm{Y} 2$ is 0.108 . While the indirect effect of X2 through $\mathrm{Y} 1$ on $\mathrm{Y} 2$ is $(0.508 \times 0.700=0.355)$. Based on the results of this calculation, it is known that the value of the direct effect is 0.108 and indirect effect is 0.355 , which means that the value of the indirect effect is greater than the value of the direct effect. These results indicate that taxpayer awareness can mediate a partial relationship between socialization and taxpayer compliance.

\section{Discussion}

\subsection{Taxpayer Knowledge and Awareness}

The results have shown that taxpayer knowledge had a positive effect on taxpayer awareness. Based on the theory of specificity attribution, taxpayer knowledge and understanding of taxpayers were used to determine behavior towards paying tax awareness. If a taxpayer tries to know the tax regulations through the internet media and the taxpayer is aware and understands that paying taxes is necessary, this method works to increase taxpayer awareness. The higher the taxpayer's knowledge of taxation, the better the taxpayer's understanding of taxes. The results of this study support the results of previous studies which state that tax knowledge has a positive effect on taxpayer awareness (Syahputri et al., 2014; Manuputty \& Sirait, 2016; Setiyani et al., 2018; Zahra, 2017; Kurniati et al., 2016; Setyorini, 2016; Jaya, Ratnawati, \& Sardjono, 2017).

\subsection{Tax Socialization and Taxpayer Awareness}

The results have shown that tax socialization had a positive effect on taxpayer awareness. Based on the theory of consistency attribution, if the taxation socialization given previously is considered less effective by the taxpayer, it can make the taxpayer 
less aware of paying taxes. Therefore, taxation socialization should be made more effective, so that taxpayers remain consistent at the same level of awareness. The results of this study are supported by the results of research conducted by others (e.g. Syahputri et al., 2014; Yuwono, 2015; Setyorini, 2016; Herawati et al., 2017; Astuti, 2017; Boediono et al., 2018) that tax socialization has a positive effect on taxpayer awareness. Thus, more intensive tax socialization will increase taxpayer awareness to pay taxes.

\subsection{Taxpayer Awareness and Taxpayer Compliance}

The results have shown that taxpayer awareness had a positive effect on taxpayer compliance. Based on attribution theory, human behavior is caused by external and internal factors. Awareness of taxpayers is an internal factor in the form of an inner urge to behave obediently formed by taxation knowledge, positive perceptions about taxes, and characteristics of taxpayers. Knowledge of taxation provides an understanding of taxpayers about the role of taxes for a country so that taxpayers have a positive assessment of taxes. Taxpayers who have a positive evaluation of taxes do not consider paying taxes a burden. This is consistent with research conducted by others (e.g. Ibtida, 2010; Astuti, 2017; Lestari dan Wicaksono, 2017; Hartana \& Merkusiwati, 2018; Bernard et al., 2018; Nurkhin et al., 2018; Lestari, 2018) that awareness of taxpayers has a positive effect on taxpayer compliance. The higher the level of taxpayers understanding, the better awareness of paying tax obligations, which, in turn, increases taxpayer compliance.

\subsection{Taxpayer Knowledge and Taxpayer Compliance}

The results have shown that taxpayer knowledge had a positive effect on taxpayer compliance. Based on the attribution theory, taxpayers' knowledge of free worker tax regulations was an internal cause that can influence taxpayers to pay taxes. Taxpayers who understand and understand tax regulations, taxpayers are becoming more aware of the importance of paying taxes. Taxpayers can feel the benefits directly or indirectly to increase taxpayer compliance. This is in line with research conducted by other researchers (Manuputty, 2016; Wijaya \& Arisman, 2016; Widawati, 2017; Astuti, 2017; Setiyani et al., 2018; Nurkhin et al., 2018; Bernard et al., 2018) that tax knowledge has a positive effect on taxpayer compliance. The higher the tax knowledge, the better the taxpayer's understanding of taxation and this will encourage taxpayers to be more compliant with the general tax provisions.

\subsection{Tax Socialization and Taxpayer Compliance}

The results have shown that tax information dissemination did not directly influence tax compliance. Based on attribution theory, a person's behavior is influenced by internal factors or external factors. Both of these factors are expected to motivate taxpayers to be obedient in paying taxes. But every individual has a different level of awareness. Therefore, with routine tax socialization, it certainly can make people aware and respectful in paying tax obligations. It is in line with research conducted by other reseachers (e.g. Winerungan, 2013; Yuliasari, 2015; Veronica, 2015; Lianty et al., 2017; Setyaningrum, 2017; Lestari, 2018) that tax socialization does not directly affect the compliance of taxpayers. Tax socialization conducted intensively and continuously to the public still cannot affect taxpayer compliance to pay taxes.

\section{Conclusion}

The results of this study have indicated that taxpayer knowledge and socialization had a significant effect on taxpayer awareness. It shows that better taxpayer's knowledge will encourage the level of taxpayer awareness. Likewise, intense tax socialization can increase taxpayer awareness in paying taxes. Awareness of taxpayers has a significant effect on taxpayer compliance. The results of this study have indicated that taxpayers who are aware of and know the actual function of taxation will be more compliant with taxation rules and general provisions. This study is expected to be used as an evaluation for stakeholders to become more active in applying efforts to increase awareness and compliance of taxpayers, for example conducting tax socialization to the public regularly so that taxpayers have more profound knowledge about taxes to carry out tax obligations. The limitations of this study are 1). The sample used is only in Semarang City - Indonesia, and 2). The variables used are still limited to taxpayer knowledge, tax socialization, taxpayer awareness, and taxpayer compliance. Therefore, future research needs to add other variables such as education level and income as independent variables.

\section{Acknowledgement}

The authors would like to thank to anonymous referees for constructive comments on earlier version of this paper. 


\section{References}

Andiko, M. C., Asnawi, \& Pangayow. (2018). Pengaruh Pengetahuan Perpajakan, Ketegasan Sanksi Pajak, Tax Amnesty, Lingkungan Wajib Pajak Terhadap Kepatuhan Wajib Pajak (Studi Kasus di Kantor Pelayanan Pajak Pratama Jayapura). Jurnal Akuntansi Dan Keuangan Daerah, 13(2).

Astuti, P. T. (2017). Pengaruh Sosialisasi, Pengetahuan Pajak, dan Kualitas Pelayanan Terhadap Tingkat Kepatuhan Pajak Bumi dan Bangunan Dengan Kesadaran Sebagai Variabel Intervening (Studi Pada Wajib Pajak Bumi dan Bangunan di Kabupaten Sukoharjo). Institut Agama Islam Negeri Surakarta, Surakarta.

Bernard, O. M., Memba, F. S., \& Oluoch, O. (2018). Influence of cost of tax compliance on tax compliance among investors in the export processing zones in Kenya. International Journal of Scientific Research and Management, 6(10).

Boediono, T., Sitawati, R., \& Harjanto, S. (2018). Analisis Pengaruh Sosialisasi Perpajakan Terhadap Kepatuhan Wajib Pajak Dengan Kesadaran Sebagai Variabel Mediasi. Jurnal Penelitan Ekonomi dan Bisnis, 3(1). https://doi.org/10.33633/jpeb.v3i1.2286

Budhiartama, I. G. P., \& Jati, I. K. (2016). Pengaruh sikap kesadaran Wajib Pajak Dan Pengetahuan Perpajakan pada kepatuhan membayar Pajak Bumi dan Bangunan. E-Jurnal Akuntansi Universitas Udayana, 15(2).

Chau. (2009). A Critical Review Of Fischer Tax Compliance Model: A Research Synthesis (Vol. 1). Hongkong.

Endaryanti, R. N. (2017). Pengaruh Kualitas Pelayanan, Sanksi Perpajakan, Biaya Kepatuhan Pajak, Penerapan E-filing dan Pengetahuan Pajak Terhadap Kepatuhan Wajib Pajak (Studi Empiris Pada KPP Pratama Surakarta). Universitas Muhammadiyah, Surakarta.

Hardiningsih, P., \& Yulianawati, N. (2011). Faktor-Faktor Yang Mempengaruhi Kemauan Membayar Pajak. Jurnal Dinamika Keuangan dan Perbankan, 3(1).

Harinurdin. (2009). Perilaku Kepatuhan Wajib Pajak Badan. Jurnal Ilmu Administrasi Dan Organisasi, 16(2).

Hartana, I. M. G., \& Merkusiwati, N. K. L. A. (2018). Sosialisasi Perpajakan Memoderasi Pengaruh Kesadaran Wajib Pajak dan Sanksi Perpajakan pada Kepatuhan Wajib Pajak. E-Jurnal Akuntansi Universitas Udayana, 25(2). https://doi.org/10.24843/EJA.2018.v25.i02.p26

Herawati, H., Lusiana, S., \& Tabroni, R. (2017). The effectiveness of the socialization strategy of taxation regulation in establishing taxpayer's objectives in tax rights and obligations. Proceedings of the International Conference on Administrative Science (ICAS 2017), 43. https://doi.org/10.2991/icas-17.2017.24

Herryanto, M., \& Toly, A. A. (2013). Pengaruh Kesadaran Wajib Pajak, Kegiatan Sosialisasi Perpajakan, dan Pemeriksaan Pajak terhadap Penerimaan Pajak Penghasilan di KPP Pratama Surabaya Sawahan. Tax and Accounting Review, 1(1).

Ibtida, R. (2010). Pengaruh Kesadaran Wajib Pajak dan Pelayanan Fiskus Terhadap Kinerja Penerimaan Pajak Dengan Kepatuhan Wajib Pajak Sebagai Variabel Intervening (Studi Pada Wajib Pajak di Jakarta Selatan) (Skripsi). Universitas Sebelas Maret, Surakarta.

Indrawan, D. (2014). Pengaruh Pengetahuan dan Pemahaman, Efektifitas Sistem Perpajakan, dan Pelayanan Fiskus Terhadap Kemauan Membayar Pajak Dengan Kesadaran Membayar Pajak Sebagai Variabel Intervening. (Studi Empiris pada KPP Pratama Bangkinang). Jurnal Online Mahasiswa Fakultas Ekonomi, 1(2).

Jatmiko, A. N. (2006). Pengaruh Sikap Wajib Pajak Pada Pelaksanaan Sanksi Denda, Pelayanan Fiskus dan Kesadaran Perpajakan Terhadap Kepatuhan Wajib Pajak (Studi Empiris Terhadap Wajib Pajak Orang Pribadi di Kota Semarang). Diponegoro, Semarang.

Jaya, A., Ratnawati, T., \& Sardjono, S. (2017). Analysis of effect of knowledge and service quality, accessibility of information, awareness and behavior of taxpayers and impact on satisfaction and compliance with taxpayers of land and buildings in the city Batam Island Riau province. International Journal of Business and Management Invention, 6(8).

Kurniati, D. H., M Djudi, M., \& Saifi, M. (2016). Pengaruh Pengetahuan Perpajakan dan Kualitas Pelayanan Terhadap Kesadaran Wajib Pajak Dalam Menyampaikan Surat Pemberitahuan (SPT) Tahunan. Jurnal Mahasiswa Perpajakan, 9(1).

Kurniawan, H., Kumadji, S., \& Yaningwati, F. (2014). Pengaruh Sosialisasi Perpajakan dan Persepsi Wajib Pajak Tentang Pelaksanaan Sensus Pajak Nasional Terhadap Kesadaran Wajib Pajak Orang Pribadi (Survei Terhadap Wajib Pajak Orang Pribadi di Wilayah Banyuwangi). Jurnal Mahasiswa Perpajakan, 3(1).

Lestari, I. (2018). Pengaruh Kesadaran Wajib Pajak, Sanksi Pajak, Sosialisasi Pajak, dan Kualitas Pelayanan Pajak Terhadap Kepatuhan Wajib Pajak Orang Pribadi Pada Wilayah Kantor Pelayanan Pajak Pratama Surakarta. Universitas Muhammadiyah, Surakarta.

Lestari, T., \& Wicaksono, M. (2017). Effect of Awareness, Knowledge and Attitude of Taxpayers Tax Compliance for Taxpayers in Tax Service Office Boyolali. International Journal of Economics, Business and Accounting Research, 1(1).

Lianty, R. A. M., Hapsari, D. W., \& Kurnia. (2017). Pengetahuan Perpajakan, Sosialisasi Perpajakan, dan Pelayanan Fiskus Terhadap Kepatuhan Wajib Pajak. Jurnal Riset Akuntansi Kontemporer, 9(2).

Manuputty, I. G., \& Sirait, S. (2016). Pengaruh Pengetahuan Perpajakan dan Penerapan Self Assesment System Terhadap Kesadaran Wajib Pajak Serta Dampaknya Terhadap Kepatuhan Wajib Pajak Pada KPP Pratama Jakarta Panjaringan. Media Akuntansi Perpajakan, 1(2). 
Marjan, R. M. (2014). Pengaruh Kesadaran Wajib Pajak, Pelayanan Fiskus, dan Sanksi Pajak Terhadap Tingkat Kepatuhan Formal Wajib Pajak (Studi di Kantor Pelayanan Pajak Pratama Makassar Selatan) (Thesis, Universitas Hasanuddin Makassar).

Melando, N., \& Waluyo. (2013). Pengaruh Pelayanan Fiskus, Persepsi Atas Efektivitas Sistem Perpajakan, Pengetahuan Pajak, dan Kesadaran Wajib Pajak Terhadap Kepatuhan Wajib Pajak Orang Pribadi (Studi di KPP Pratama Tigaraksa). Ultima Accounting, 5(2).

Muliari, N. K., \& Setiawan, P. E. (2011). Pengaruh Persepsi Tentang Sanksi Perpajakan dan Kesadaran Wajib Pajak Pada Kepatuhan Pelaporan Wajib Pajak Orang Pribadi di Kantor Pelayanan Pajak Pratama Denpasar Timur. Jurnal Ilmiah Akuntansi dan Bisnis, 6(1).

Nurkhin, A., Novanty, Muhsin, \& Sumiadji. (2018). The Influence of Tax Understanding, Tax Awarenessand Tax Amnesty toward Taxpayer Compliance. Jurnal Keuangan Dan Perbankan. https://doi.org/10.26905/jkdp.v22i2.1678

Nurmantu, S. (2005). Pengantar Perpajakan-Safri Nurmantu - Google Buku (3rd ed.).

Sandjojo, N. (2011). Metode Analisis Jalur (Path Analysis) dan Aplikasinya. Jakarta: Pustaka Sinar Harapan.

Saragih, S. F. (2013). Analisis Pengaruh Sosialisasi Perpajaka, Kualitas Pelayanan Fiskus dan Sanksi Perpajakan Terhadap Kepatuhan Wajib Pajak Orang Pribadi di Kantor Pelayanan Pajak (KPP) Pratama Medan Timur (Skripsi USU, Universitas Sumatera Utara).

Satiti, H. (2016). Analisis Faktor-Faktor Yang Mempengaruhi Kesadaran Wajib Pajak Dalam Membayar Pajak Bumi dan Bangunan Perdesaan dan Perkotaan (Universitas Gadjah Mada).

Setiyani, N. M., Andini, R., \& Oemar, A. (2018). Pengaruh Motivasi Wajib Pajak dan Pengetahuan Perpajakan Terhadap Kepatuhan Wajib Pajak Orang Pribadi Dengan Kesadaran Wajib Pajak Sebagai Variabel Intervening. Jurnal Ilmiah Mahasiswa S1 Akuntansi Universitas Pandanaran, 4(4).

Setyaningrum, T. A. (2017). Pengaruh Sosialisasi Dengan Mediasi Kesadaran Terhadap Kepatuhan Wajib Pajak Bumi dan Bangunan di Kota Pekalongan. 8.

Setyorini, C. (2016). The Influence of Tax Knowledge, Managerial Benefit and Tax Socialization Toward Taxpayer's Willingness to Pay SME's Tax. Acta Universitatis Danubius. Oeconomica, 12(5).

Sucipto. (2016, November 21). Kesadaran Masyarakat Membayar Pajak Masih Rendah.

Sugeng, W. (2012). Teori dan Aplikasi: Mengurus Pajak itu Mudah. Mojokerto: Gramedia Direct.

Suryani, F., Fadrul, \& Pujiono. (2018). Pengaruh dari Pengetahuan Wajib Pajak, Kesadaran Wajib Pajak, dan Kualitas Pelayanan Fiskus Terhadap Kepatuhan Wajib Pajak di Kota Pekanbaru. Bilancia Jurnal Ilmiah Akuntansi, 2(4).

Susmita, P. R., \& Supadmi, N. L. (2016). Pengaruh Kualitas Pelayanan, Sanksi Perpajakan, Biaya Kepatuhan Pajak, dan Penerapan E-filing Pada Kepatuhan Wajib Pajak. E-Jurnal Akuntansi Universitas Udayana, 14(2).

Syahputri, M. S., Ariswoyo, S., \& Sinulingga, U. (2014). Faktor Yang Mempengaruhi Kesadaran Wajib Pajak PBB (Pajak Bumi dan Bangunan). Saintia Matematika, 2(3).

Syarifudin, A. (2016). Pengaruh Kualitas Pelayanan Petugas Pajak, Sanksi Perpajakan, dan Biaya Kepatuhan Pajak Terhadap Kepatuhan Wajib Pajak (Thesis, Universitas Pasundan Bandung).

Tiraada. (2013). Kesadaran Perpajakan, Sanksi Pajak, Sikap Fiskus Terhadap Kepatuhan WPOP di Kabupaten Minahasa Selatan. Jurnal EMBA, 1(3).

Undang-Undang 9-1994: Perubahan UU 6-1983 ttg KUP. (2019). Retrieved July 10, 2019, from Kementrian Keuangan website: https://jdih.kemenkeu.go.id/fullText/2000/16TAHUN2000UU.htm

Veronica, A. (2015). Pengaruh Sosialisasi Perpajakan, Pelayanan Fiskus, Pengetahuan Pajak, Persepsi Pengetahuan Korupsi, dan Sanksi Perpajakan Terhadap Kepatuhan Wajib Pajak Orang Pribadi (WPOP) pada KPP Pratama Senapelan Pekanbaru.

Widawati. (2017). Pengaruh Kualitas Pelayanan Perpajakan, Pengetahuan Peraturan Perpajakan, Sosialisasi Perpajakan dan Sanksi Pajak Terhadap Kepatuhan Wajib Pajak (Studi Empiris Wajib Pajak Orang Pribadi di KPP Pratama Boyolali) (Thesis, Institut Agama Islam Negeri Surakarta).

Wijaya, S., \& Arisman, A. (2016). Pengaruh Pengetahuan Pajak, Sanksi Pajak, dan Kesadaran Wajib Pajak terhadap Kepatuhan Wajib Pajak Dengan Kemauan Membayar Pajak Sebagai Intervening (Studi Kasus KPP Pratama Ilir Barat di Kota Palembang). STIE MDP.

Winerungan, O. L. (2013). Sosialisasi Perpajakan, Pelayanan Fiskus dan Sanksi Perpajakan Terhadap Kepatuhan WPOP di KPP Manado dan KPP Bitung. 11.

Yuliasari, W. S. (2015). Pengaruh Sosialisasi Perpajakan, Pelayanan Fiskus, dan Sanksi Terhadap Kepatuhan Wajib Pajak Orang Pribadi (Studi Pada Wajib Pajak Orang Pribadi di KPP Pratama Ponororgo). 4(2).

Yuwono, Z. D. (2015). Pengaruh Sosialisasi Terhadap Kesadaran dan Kepatuhan Wajib Pajak Bumi dan Bangunan di Kota Kediri. Universitas Nusantara PGRI Kediri.

Zahra, I. N. (2017). Pengaruh Persepsi Atas Efektifitas Sistem Perpajakan dan Pengetahuan Pajak Terhadap Kepatuhan Wajib Pajak Dengan Kesadaran Membayar Pajak Sebagai Variabel Intervening (Studi Pada WPOP Yang Terdaftar di KPP Pratama Surakarta) (Skripsi, IAIN Surakarta). 
(C) 2020 by the authors; licensee Growing Science, Canada. This is an open access article distributed under the terms and conditions of the Creative Commons Attribution (CC-BY) license (http://creativecommons.org/licenses/by/4.0/). 